\title{
PENGARUH BUDAYA ORAGANISASI DAN KEPEMIMPINAN TERHADAP KINERJA KARYAWAN ( Studi Kasus Pada PT. SNS Cabang Madiun)
}

\author{
Budi Santoso $^{1)}$ Karuniawati Hasanah ${ }^{2)}$ \\ ${ }^{1)}$ Program Studi Manajemen Ekonomi Dan Bisnis \\ Universitas PGRI Madiun \\ ${ }^{2)}$ Dosen Universitas PGRI Madiun
}

\begin{abstract}
This study aims to determine the effect of leadership and organizational culture on employee performance at PT. SNS Madiun. The method used in this study using quantitative research methods. And samples used in this study as many as 45 employees. Based on the results of multiple linear regression analysis obtained that the Organizational Culture and Leadership Significant positive influence on employee performance. The better the culture of the organization, then the employee's performance will increase. Leadership positive influence on employee performance means that if the leadership is getting better, then the employee's performance will increase.
\end{abstract}

Keywords: Organizational Culture, Leadership, Employee Performance

PENDAHULUAN

Persaingan pada saat sekarang ini sudah semakin tinggi, bukan hanya persaingan lokal tapi juga sudah dalam persaingan global, tantangan yang langsung kita hadapi adalah globalisasi dengan segala implikasinya. Organisasi agar tetap eksis maka harus berani menghadapinya yaitu menghadapi perubahan dan memenangkan persaingan. Sumber daya yang dimiliki oleh perusahaan seperti modal, metode dan mesin tidak bisa memberikan hasil yang optimum apabila tidak didukung oleh sumber daya manusia yang mempunyai kinerja yang optimum. Pabundu (2014:121) menjelaskan bahwa perusahaan membutuhkan karyawan yang mampu bekerja lebih baik dan lebih cepat, sehingga diperlukan karyawan yang mempunyai kinerja (job performance) yang tinggi.

Setiap organisasi selalu berusaha meningkatkan kinerja karyawan, dengan harapan apa yang menjadi tujuan organisasi bisa tercapai. Berbagai cara akan ditempuh organisasi dalam meningkatkan kinerja karyawannya, misalnya dengan melalui peningkatan kompetensi karyawan (training), menerapkan kedisiplinan yang ketat dan 
penanaman budaya perusahaan sebagai dasar dari perusahaan.

Budaya organisasi merupakan salah satu faktor yang dipandang mempengaruhi kinerja karyawan. Budaya organisasi dikenal luas sebagai fondasi sistem dan aktivitas manajemen dalam setiap organisasi (Pabundu, 2014:131). Budaya organisasi dipandang sebagai nilainilai bersama dan norma-norma perilaku yang diyakini dan dianut oleh anggota-anggota organisasi. Nilai dan norma perilaku tersebut menciptakan pendekatan yang digunakan anggota organisasi dalam melaksanakan pekerjaan dan mengatasi permasalahan yang dihadapi. Banyak pakar menyebutkan bahwa budaya organisasi dapat menjadi basis adaptasi dan kunci keberhasilan organisasi, sehingga banyak penelitian dilakukan untuk mengidentifikasi nilai-nilai atau norma-norma perilaku yang bisa memberikan kontribusi besar bagi keberhasilan organisasi (Edy Sutrisno, 2010). Banyak yang mencoba menghubungkan budaya organisasi dengan variabel variabel sumber daya manusia yang penting, khususnya kinerja karyawan.

Faktor penting yang lain menentukan kinerja karyawan adalah kemampuan organisasi beradaptasi dengan perubahan lingkungan menurut Slamet (2009:46) adalah kepemimpinan (leadership). Kepemimpinan menggambarkan hubungan antara pemimpin (leader) dengan yang dipimpin (follower) dan bagaimana seorang pemimpin mengarahkan follower akan menentukan sejauh mana follower mencapai tujuan atau harapan pimpinan. Konsep kepemimpinan yang berkembang pesat adalah konsep kepemimpinan transaksional dan tranformasional yang di populerkan oleh Bass (Soekanto, 2013:257). Kedua konsep kepemimpinan tersebut berbasiskan pada gaya, perilaku dan situasi yang meliputi seorang pemimpin. Kepemimpinan transaksional berdasarkan prinsip pertukaran imbalan antara pemimpin dengan bawahan dimana pemimpin mengharapkan imbalan berupa kinerja bawahan yang tinggi sementara bawahan mengharapkan imbalan dan penghargaan secara ekonomis dari pemimpin (Humphreys, 2002; Rafferty \&Griffin 2004; Sarros \& Santora 2001). Sedangkan kepemimpinan tranformasional mendasarkan diri pada prinsip pengembangan bawahan (follower development). Pemimpin mengembangkan dan mengarahkan potensi dan kemampuan bawahan untuk mencapai bahkan melampaui tujuan organisasi (Dviret al,2002).

Berdasarkan penelitian terdahulu oleh Muhrodi (2012) yang berjudul Pengaruh Kepemimpinan, Budaya Organisasi terhadap Kinerja Karyawan pada PDAM Tirta Bangkinang menyimpulkan: Dengan variabel Kepemimpinan $\left(\mathrm{X}_{1}\right)$ dan Budaya Organisasi $\left(\mathrm{X}_{2}\right)$ dapat mempengaruhi variabel Kinerja $\left(\mathrm{Y}_{1}\right)$.

Rusdan Arif (2010) dalam hasil penelitiannya yang berjudul Pengaruh Budaya Organisasi, Kepemimpinan Terhadap Kinerja Karywan di PT. Bank Mega Cabang Semarang menyimpulkan: Hasil analisis regresi linier berganda diperoleh bahwa faktor 
Budi, Budaya Organisasi dan Kepemimpinan Terhadap Kinerja

yang paling mempengaruhi kinerja karyawan adalah kepemimpinan, hal ini dibuktikan dengan nilai standardized coeficient yang terbesar. Kepemimpinan berpengaruh secara positif dan signifikan terhadap kinerja karyawan. Semakin baik kepemimpinan, maka kinerja karyawan akan meningkat. Budaya organisasi berpengaruh positif terhadap kinerja karyawan. Artinya apabila budaya organisasi semakin baik, maka kinerja karyawan akan meningkat.

Penelitian lain juga dilakukan oleh Dede Sumarni (2011) dalam hasil penelitiannya yang berjudul Pengaruh Kepemimpinan, Budaya Organisasi Terhadap Kinerja Karyawan di PDAM Tirta Moedal Semarang menyimpulkan bahwa secara parsial terdapat pengaruh kepemimpinan terhadap kinerja karyawan PDAM Tirta Moedal Semarang dan secara parsial tidak ada pengaruh signifikan budaya organisasi terhadap kinerja karyawan PDAM Tirta Moedal Semarang. Secara simultan ada pengaruh kepemimpinan dan budaya organisasi terhadap kinerja karyawan PDAM Tirta Moedal Semarang.

Dalam penelitian sebelumnya telah di jelaskan pengaruh budaya organisasi dan kepemimpinan dalam beberapa perusahaan, dimana penelitian sebelumnya itu menjadi referensi penulis untuk melakukan penelitian saat ini. Perbedaan dalam penelitian ini adalah objek penelitian dan jumlah responden yang di teliti. Pada penelitian ini budaya organisasi dan kepemimpinan yang diteliti penulis adalah meneliti PT Sinar Niaga Sejahtera (PT SNS) Cabang Madiun.

Tudung Group atau PT Tudung Putra Putri Jaya adalah sebuah perusahaan yang mempunyai dua jenis usaha yaitu industry food dan agribusiness. Untuk industry food Tudung Group memiliki perusahaan yang di beri nama PT Garuda food Beverage Jaya yang mana PT Garuda food Beverage Jaya ini memiliki tiga anak perusahaan yaitu PT Garuda Food Putra Putri Jaya, PT Suntory Garuda Beverage, PT Sinar Niaga Sejahtera. Sedangkan untuk agribusiness juga dibagi menjadi tiga perusahaan yaitu PT Mekar Tani, PT Garuda Bumi Perkasa, PT Hanusentra Agro Lestari. Untuk PT Sinar Niaga Sejahtera (PT SNS) merupakan bagian dari PT Garuda food Beverage Jaya yang bergerak di bidang distribusi.

Dalam menjalankan bisnis usahanya Tudung Group atau PT Tudung Putra Putri Jaya menyadari bahwa pentingnya satu pemikiran yang searah dari semua karyawan maka Tudung group atau PT Tudung Putra Putri Jaya membuat suatu pola pemikiran karyawan atau dalam bentuk budaya organisasi yang di sebut Tudung Basic Mentality (TBM). Tudung Basic Mentality (TBM) sebagai serangkaian pengertian sekaligus sikap dasar yang harus ada pada diri semua karyawan Tudung Group dalam menghayati hidup dan melaksanakan pekerjaan sehari-hari sebagai budaya organisasi yaitu Bersyukur atas Anugerah Tuhan (Be Grateful to God), Semangat untuk Sukses (Winning Spirit), Pelayanan kepada Stakeholders (Service to 
Budi, Budaya Organisasi dan Kepemimpinan Terhadap Kinerja

Stakeholders), Berpikir Kreatif dan Inovatif (Creative and Innovative Thinking),

Berkesinambungan

Perbaikan

Improvement).

Hasil observasi yang didapati adalah dalam waktu lima tahun (20112016) terjadi mutasi pemimpin dari PT Sinar Niaga Sejahtera (PT SNS) Cabang Madiun sebanyak 3 pemimpin. Pada keadaan normal seharusnya dalam periode itu tidak terjadi pergantian pemimpin seperti pada area lainnya dalam PT Sinar Niaga Sejahtera region JATIM. Hal ini menunjukan bahwa kinerja dari pemimpin PT Sinar Niaga Sejahtera (PT SNS) Cabang Madiun belum sesuai yang diharapkan oleh perusahaan. Dengan adanya mutasi tersebut diharapkan ada perubahanperbaikan kinerja sehingga tujuan perusahaan tercapai.

Menurut Wibowo (2007:7) kinerja merupakan hasil pekerjaan yang mempunyai hubungan kuat dengan tujuan strategis organisasi, kepuasan konsumen dan memberikan kontribusi pada ekonomi. Kinerja karyawan PT Sinar Niaga Sejahtera Cabang Madiun juga dapat diukur melalui penyelesaian tugasnya secara efektif dan efisien serta melakukan peran dan fungsinya dan itu semua berhubungan positif bagi keberhasilan perusahaan.

Untuk mengetahui bagaimana budaya organisasi dan kepemimpinan yang berkontribusi terhadap tingkat kinerja karyawan, maka penulis melakukan penelitian tentang masalah budaya organisasi dan kepemimpinan yang ada pada perusahaan PT Sinar Niaga Sejahtera (PT SNS) Cabang
Madiun dengan judul "PENGARUH BUDAYA ORAGANISASI DAN KEPEMIMPINAN TERHADAP KINERJA KARYAWAN ( Studi Kasus Pada PT. SNS Cabang Madiun)"

Dari latar belakang yang diuraikan secara singkat diatas,maka rumusan masalah dalam penelitian ini diuaraikan sebagai berikut :

1. Apakah Budaya Organisasi berpengaruh terhadap Kinerja karyawan?

2. Apakah Kepemimpinan berpengaruh terhadap Kinerja karyawan?

Tujuan dari penelitian ini adalah sebagai berikut :

1. Untuk mengetahui pengaruh budaya organisasi terhadap kinerja karyawan

2. Untuk mengetahui pengaruh kepemimpinan terhadap kinerja karyawan.

\section{METODE PENELITIAN}

Penelitian dilakukan di PT Sinar Niaga Sejahtera Cabang Madiun yang beralamatkan di Jalan Mayjend Sungkono nomor 14, Kecamatan Demangan, Kota Madiun, Provinsi Jawa Timur. Waktu pelaksanaan penelitian kurang lebih enam bulan yaitu bulan Januari sampai dengan Juni 2016.

Populasi merupakan kelompok subjek yang hendak dikenai generalisasi hasil penelitian. "Populasi" ini merupakan "kelompok subjek yang harus memiliki ciri-ciri atau karakteristik bersama" (Saifuddin 
Budi, Budaya Organisasi dan Kepemimpinan Terhadap Kinerja

Azwar, 2009:77). Dari pengertian populasi tersebut, maka populasi dalam penelitian ini adalah seluruh karyawan PT Sinar Niaga Sejahtera Cabang Madiun. Jumlah keseluruhan populasi dalam penelitian ini ada 45 orang.

Sedangkan sampel dalam penelitian ini adalah seluruh karyawan PT Sinar Niaga Sejahtera Cabang Madiun yang berjumlah 45 orang. Jadi penelitian ini adalah penelitian populasi atau totally sampling (sampel jenuh) yaitu teknik penentuan sampel bila semua anggota populasi digunakan sebagai sampel (Sugiyono, 2010:120).

Variabel adalah obyek penelitian atau apa yang menjadi titik perhatian suatu penelitian (Suharsimi, 2006:118). Variabel yang diteliti harus sesuai dengan permasalahan dan tujuan yang ingin dicapai dalam penelitian. Variabel yang digunakan adalah variabel bebas (Independent $(\mathrm{X})$ ) yakni Budaya Organisasi dan Kepemimpinan sedangkan variabel terikat (Dependen $(\mathrm{Y}))$ adalah Kinerja Karyawan .

Menurut Sugiyono (2006:74), sample adalah bagian dari jumlah dan karakteristik yang dimiliki oleh populasi tersebut. Dalam pemilihan sampel pada penelitian ini menggunakan metode Probability Sampling, adalah teknik pengambilan sampel yang memberi peluang / kesempatan yang sama bagi setiap unsur atau anggota populasi untuk dipilih menjadi sampel (Sugiyono, 2006:77).
Menurut Suharsimi Arikunto (2003: 120), apabila jumlah populasi kurang dari 100 lebih baik diambil semua sehingga penelitiannya merupakan penelitian populasi. Selanjutnya jika jumlah populasinya besar dapat diambil antara 10-15\% atau $20-25 \%$ atau lebih.

Dalam penelitian ini populasi yang digunakan adalah sebesar 300 debitur. Agar hasil dari penelitian ini cukup akurat kebenarannya, maka dari populasi sebesar 300 debitur diambil sebagian (sampel) yaitu $25 \%$ dari populasi yang ada di lokasi penelitian sehingga terkumpul sebanyak 75 orang yang menjadi sampel.

Instrumen pengumpulan data pada penelitian ini adalah angket atau kuesioner.Menurut Arikunto (2006:151) angket atau kuesioner adalah pernyataan tertulis yang digunakan untuk memperoleh informasi dari respon dan dalam arti laporan tentang pribadi atau hal-hal yang ia ketahui.

Angket yang digunakan dalam penelitian ini adalah angket tertutup dengan kemungkinan jawaban yang telah tersedia.Mengenai alternatif jawaban dalam angket, penulis menggunakan skala ordinal.Menurut Sugiyono (2013) skala likert adalah skala pengukuran yang tidak hanya menyatakan kategori, tetapi juga menyatakan peringkat construct yang diukur.

Untuk setiap pilihan jawaban diberi skor, maka responden harus menggambarkan, mendukung pernyataan (item positif) atau tidak 
Budi, Budaya Organisasi dan Kepemimpinan Terhadap Kinerja

mendukung pernyataan (item negatif).Skor atas pilihan jawaban untuk kuesioner yang diajukan untuk pernyataan positif adalah sangat setuju (5), setuju (4), kurang setuju (3), tidak setuju (2), sangat tidak setuju (1).

Uji validitas dilakukan melalui analisis data Correlated-Item Total Correlation yaitu dengan cara mengkorelasikan masing-masing skor item dengan skor total dan melakukan korelasi terhadap nilai koefisien korelasi dengan dasar pengambilan keputusan Jika nilai $r_{\text {hitung }}>r_{\text {tabel }}$, maka pernyataan dalam kuesioner dinyatakan valid, sedangkan jika nilai $r_{\text {hitung }}<r_{\text {tabel }}$, maka item pertanyaan dalam kuesioner dinyatakan tidak valid. Ghozali (2013:53).

Uji reliabilitas dengan cara melihat Cronbach Alpha dengan signifikansi yang digunakan lebih besar dari 0,70. Suatu konstruk atau variabel dikatakan reliable jika memberikan nilai Cronbach Alpha> 0,70 (Ghozali, 2013:48).

$$
\text { Uji asumsi Normalitas }
$$

menggunakan metode KolmogrovSmirnov jika hasil angka signifikansi (Sig) lebih kecil dari 0,05 maka data tidak terdistribusi normal.Ghozali (2013:160). Uji heteroskedastisitas adalah dengan melihat grafik scatterplot antaranilai prediksi variabel terikat (ZPRED) dengan residualnya (SRESID). Dasar pengambilan keputusan uji tersebut yaitu jika ada titik-titik yang membentuk pola tertentu yang teratur seperti bergelombang, melebar kemudian menyempit, maka mengindikasikan adanya heteroskedastisitas. Jika tidak terdapat pola tertentu yang jelas, serta titik-titik menyebar diatas dandibawah angka nol pada sumbu $\mathrm{Y}$ maka mengindikasikan tidak terjadi heteroskedastisitas. Menurut Ghozali (2013:139).

Uji Autokorelasi dilihat dari uji DurbinWaston (DW Test). Dengan dasar pengampilan keputusan jika Du < $\mathrm{d}<$ 4-du maka dinyatakan tidak terdapat autokorelasi. Ghozali (2013:110) .

Uji multikolinieritas dilakukan dengan melihat nilai tolerance dan lawannya (2) variance inflation factor ( VIF ). Jika nilai tolerance yang rendah sama dengan nilai VIF tinggi ( karena VIF $=1 /$ Tolerance $)$. Nilai cut off yang umum dipakai untuk menunjukkan adanya multikolinieritas adalah Nilai Tolerance $\leq 0,10$ atau sama dengan nilai VIF $\geq 10$. Ghozali (2013:105).

Teknik analisis data yang dipaki adalah regresi linier berganda (multiple regression). Untuk menguji pengaruh variabel penelitian secara parsial digunakan uji t. Dengan dasar pengambilan keputusan bila $t_{\text {hitung }}>$ $\mathrm{t}_{\text {tabel }}$ pada $\alpha=0,05$ artinya variabel independen secara parsial mempengaruhi variabel dependen. Bila $\mathrm{t}_{\text {hitung }}<\mathrm{t}_{\text {tabel }}$ pada $\alpha=0,05$ artinya variabel independen secara parsial tidak mempengaruhi variabel dependen. Ghozali (2013:98).

\section{HASIL PENELITIAN DAN PEMBAHASAN}

Untuk mengetahui pengaruh Budaya Organisasi dan kepemimpinan 
Budi, Budaya Organisasi dan Kepemimpinan Terhadap Kinerja

terhadap Kinerja karyawan (Y), melakukan uji regresi linier berganda. Berikut ini hasil uji regresi berganda.

Berikut adalah persamaan regresi linier berdasarkan hasil analisisi di atas:

$Y=12,430+0,039 X_{1}+2,424 X_{2}+e$

Berikut adalah persamaan regresi

\begin{tabular}{|c|c|c|c|c|}
\hline Variabel & $\begin{array}{l}\text { Koefisi } \\
\text { en } \\
\text { Regresi }\end{array}$ & $\begin{array}{l}\text { Standar } \\
\text { Eror }\end{array}$ & $\mathrm{t}_{\text {hitung }}$ & Sig \\
\hline Konstanta & $\begin{array}{r}12,43 \\
0\end{array}$ & $\begin{array}{r}27,95 \\
1\end{array}$ & 4,416 & 0,000 \\
\hline $\begin{array}{l}\text { Budaya } \\
\text { organisasi } \\
\left(\mathrm{X}_{1}\right)\end{array}$ & 0,039 & 0,455 & 2,486 & 0,011 \\
\hline $\begin{array}{l}\text { Kepemim } \\
\text { pinan } \\
\left(\mathrm{X}_{2}\right)\end{array}$ & 2,424 & 0,424 & 5,427 & 0,000 \\
\hline $\mathrm{R}^{2}$ & \multicolumn{4}{|l|}{0,422} \\
\hline $\begin{array}{l}\text { Adjusted } \\
\mathrm{R}^{2}\end{array}$ & \multicolumn{4}{|l|}{0,395} \\
\hline $\mathrm{F}_{\text {hitung }}$ & \multicolumn{4}{|c|}{$28,048 \quad$ Sig : 0,000} \\
\hline $\mathrm{N}$ & \multicolumn{4}{|l|}{45} \\
\hline $\begin{array}{l}\text { linier b } \\
\text { atas: } \\
\qquad \mathbf{Y}=\mathbf{1}\end{array}$ & & $\mathrm{nh}$ & ar & si \\
\hline
\end{tabular}

Berdasarkan persamaan di atasdapat dijelaskan bahwa kinerja karyawan PT. SNS Madiun sebelum ada variabel Budaya Organisasi sebesar 12,430. Variabel Budaya Organisasi memberikan kontribusi sebesar 0,039

Hasil analisis regresi diketahui nilai $t_{\text {hitung adalah 2,603 dengan nilai }}$ signifikansi 0,019 . Nilai $t_{\text {tabel }}$ pada taraf signifikansi 0,05 dengan jumlah $\mathrm{n}=45$ adalah 2,014. Berdasarkan data di atas diketahui bahwa nilai $t_{\text {hitung }} 2,603>$ $\mathrm{t}_{\text {tabel }}$ 2,014 dan nilai signifikansi 0,011 $<0,05$. Berarti Ho ditolak Ha diterima artinya terdapat pengaruh signifikan antara Budaya Organisasi terhadap kinerja karyawan PT. SNS Madiun.

Berdasarkan hasil regresi linier di atas dapat diketahui bahwa nilai Adjusted $\mathrm{R}^{2}$ yang dihasilkan adalah 0,427 hal ini menunjukkan bahwa variabel Budaya Organisasi $\left(\mathrm{X}_{1}\right)$, Kepemimpinan $\left(\mathrm{X}_{2}\right)$, berkontribusi terhadap model sebesar $42,7 \%$ sedangkan sisanya sebesar $57,3 \%$ disebabkan oleh faktor lain yang tidak disebutkan dalam model.

Pada penelitian ini diketahui nilai thitung adalah 2,486 dengan nilai signifikansi 0,011 . Nilai $t_{\text {tabel }}$ pada taraf signifikansi 0,05 dengan jumlah $\mathrm{n}=45$ adalah 2,140. Berdasarkan data di atas diketahui bahwa nilai thitung 2,486 > $\mathrm{t}_{\text {tabel }} 2,140$ dan nilai signifikansi 0,011 $<0,05$ menunjukkan bahwa terdapat pengaruh positif antara Budaya Organisasi terhadap kinerja karyawan PT. SNS Madiun. Dalam hal ini Budaya Organisasi di PT. SNS Madiun bisa menjadi suatu tolak ukur attitude/sikap dalam melakukan perbaikan-perbaikan untuk mencapai tujuan perusahaan.

Pengaruh Budaya Organisasi terhadap kinerja dijelaskan oleh beberapa faktor. Salah satunya adalah Share thing yakni melakukan budaya kerja dengan berdasarkan fisik ataupun suatu bentuk hal yang nyata misalnya: pakaian seragam seperti pakaian korpri untuk PNS, batik PGRI yang menjadi 
Budi, Budaya Organisasi dan Kepemimpinan Terhadap Kinerja

ciri khas organisasi tersebut. Share saying, yakni suatu bentuk Budaya Organisasi dengan berdasarkan ungkapan ungkapan untuk memberikan semangat dalam bekerja misalnya: ungkapan-ungkapan bersayap, ungkapan slogan, pameo seperti didunia pendidikan terdapat istilah "Tut Wuri Handayani". Share doing yak suatu bentuk Budaya organisasi dengan melakukan sutu kegiatan yang positif yang dilakukan dalam kurun waktu tertentu misalnya: pertemuan, kerja bakti, kegiatan sosial sebagai bentuk aktivitas rutin yang menjadi ciri khas suatu organisasi seperti istilah Mapalus di Sulawesi, Nguopin di Bali. Share feeling Yakni suatu bentuk Budaya Organisasi yang berdasarkan ungkapan perasaan untuk memberikan dukungan moral dan spiritual misalnya: turut bela sungkawa, aniversary, ucapan selamat, acara wisuda mahasiswa dan lain sebagainya semua hal tersebut memberikan pengaruh yang positif terhadap kinerja karyawan

Hasil selanjutnya menunjukkan nilai $t_{\text {hitung }}$ sebesar 5,427 dengan nilai signifikansi 0,000 . Nilai tabel pada taraf signifikansi 0,05 dengan jumlah $\mathrm{n}=45$ adalah 1,983. Berdasarkan data di atas diketahui bahwa nilai thitung 5,427 > $\mathrm{t}_{\text {tabel }} 1,983$ dan nilai signifikansi 0,000 $<0,05$ menunjukkan bahwa ada pengaruh positif dan signifikan antara kepemimpinan terhadap kinerja karyawan PT. SNS Madiun.

Pemimpin yang mampu memberikan instruksi dan pengawasan terhadap pelaksanaan tugas karyawan, pemimpin mampu memberikan kesempatan kepada karyawan untuk menyampaikan ide-ide sebagai dasar pengambilan keputusan, pemimpin memberikan kesempatan kepada bawahan untuk dilibatkan dalam pengambilan keputusan dan pelaksanaan tugas maka akan membuat karyawan lebih bersemangat dalam bekerja sehingga secara otomatis akan meningkatkan kinerja karyawan, hal ini berarti semakin baik nilai kepemimpinan pada suatu perusahaan

maka kinerja karyawan semakin meningkat.

Kepemimpinan yang baik dapat berindak sebagai varibel yang mampu mengurangi pengaruh beban kerja yang tinggi terhadap karyawan. Semakin tinggi nilai interaksi antra seorang pemimpin dan karyawan maka semakin kecil pengaruh negatif yang muncul didalam kinerja karyawan. Beban kerja yang tinggi dapat menyebabkan penurunan kinerja karyawan hal tersebut dapat dikurangi dengan kepemimpinan yang tepat. Kepemimpinan demokratis yang mampu berinteraksi dengan baik kepada karyawan, penetapan kebijakan yang tepat akan mampu memberikan dampak positif terhadap kinerja karyawan.

\section{KESIMPULAN}

Kesimpulan dari penelitian ini mengenai "Pengaruh Budaya Organisasi dan Kepemimpinan terhadap Kinerja Karyawan " pada PT.SNS Madiun, menunjukkan bahwa Budaya Oganisasi berpengaruh positif terhadap kinerja karyawan. Budaya organisasi yang sesuai dengan nilai nilai masyarakat dan dapat diterima 
Budi, Budaya Organisasi dan Kepemimpinan Terhadap Kinerja

oleh semua karyawan pasti akan memberikan dorongan positif terhadap peningkatan volume penjualan .

Pengaruh Kepemimpinanan yang sesuai, akan mampu memberikan rasa kenyamanan dan kedamaian serta mampu memberikan dorongan motivasi yang positif sehingga mampu menjalankan kinerja dengan baik hingga tercipta hasil kerja yang memuaskan untuk semua karyawan, dengan mempertahankan kepemimpinan yang sesuai, bersikap tidak ambivalensi dalam penilaian kinerja bawahannya serta selalu memberikan arahan kepada bawahannya agar selalu beriman dan bertaqwa kepada Tuhan Yang Maha Esa.

\section{DAFTAR PUSTAKA}

Abdullah,ma'ruf . 2014. Manajemen dan evaluasi kinerja karyawan. Jakarta:Aswaja presindo

Anoraga, Panji. 2009. Manajemen Bisnis. Jakarta: PT. Rineka Cipta

Arikunto, S. 2010. Prosedur

penelitian Suatu Pendekatan Praktek. Jakarta

Davis, K., \&Newstrom. J. W. 1997. Perilaku dalam Organisasi, Jilid II: Edisi ke-. 7. Jakarta: Erlangga

Dede Sumarni. 2011. Pengaruh kepemimpinan dan budaya organisasi terhadap kinerja karyawan.Semarang
Dwi Wahyu Wijayanti . pengaruh kepemimpinan dan motivasi kerja terhadap kinerja karyawan. Semarang

Eddy Sutrisno. 2010. Manajemen Sumber Daya Manusia. Jakarta: Kencana Prenada Media

Ghozali, I.2013. Aplikasi Analisis Multivariat dengan Program SPSS. Semarang:Badan Penerbit Universitas Diponegoro

Hasibuan,Melayu. 2001. Manajemen Sumber Daya Manusia. Jakarta: PT. Toko Gunung Agung

Kotter , Keller. 2007. Manajemen Pemasaran. Jakarta: PT. Indeks

Lina,dewi, 2014. Analisis pengaruh kepemimpinan dan budayaorganisasi terhadap kinerja pegawai dengan sistem reward sebagai variabel moderating . Sumatera Utara

Mathis, Robert L dan Jackson, John H, 2002. Manajemen Sumber Daya Manusia, Buku ke dua. Jakarta : Salemba Empat
Muhrodi. 2012. Pengaruh Kepemimpinan, Budaya Organisasi terhadap Kinerja Karyawan . Padang

Mulyadi, Deddy, 2015. Perilaku Organisasi dan kepemimpinan pelayanan.Bandung:Alfabeta,

Pabundu Tika. 2014.Budaya organisasi dan Peningkatan 
Budi, Budaya Organisasi dan Kepemimpinan Terhadap Kinerja

kinerja karyawan. Jakarta: Bumi Aksara Rineka Cipta

Robbins, Stephen P. 2001. Perilaku Organisasi, Jilid 1. Jakarta: PT.Prenhallindo

Rusdan Arif.2010. Pengaruh Budaya Organisasi,KepemimpinanTerh adap Kinerja Karywan di PT. Bank Mega Cabang Semarang. Semarang

Saifuddin, Azwar. 2010. Metode Penelitian. Yogyakarta : Pustaka Pelajar Offset.DKK

Siagian, Sondang P. 2007. Manajemen Sumber Daya Manusia.Jakarta: Bumi Aksara

Simamora, H., 1995. Manajemen Sumber Daya Manusia Edisi Kedua. STIE YKPN, Yogyakarta.

SimanjuntakPayaman J. 2005. Manajemen dan Evaluasi Kinerja. Jakarta: Lembaga Penerbit Fakultas Ekonomi UI

Sinambela, Lijan. (2012). Kinerja Pegawai: Teori, Pengukuran dan Implikasi. Yogyakarta: Graha Ilmu

Sindi Nova. 2015. Pengaruh budaya organisasi dan kepemimpinan transformasional terhadap efektivitas organisasi. Jogjakarta

Sugiyono. 2011. Metode Penelitian Bisnis, Edisi Kesembilan. Bandung: Alfabeta
Suharsimi.2010. Prosedur penelitian Suatu pendekatan praktik.Yogyakarta: Rineka Cipta

Wahyudi. 2009. Kepemimpinan

Kepala Sekolah dalam

Organisasi Pembelajaran

(Learning Organization).

Bandung : Alfabet 
Budi, Budaya Organisasi dan Kepemimpinan Terhadap Kinerja

28| P a g e 